\title{
ANALISA MINAT INVESTASI PASAR MODAL PADA MAHASISWA FEB DI UNIVERSITAS PAPUA
}

\author{
Witha Yuliani \\ Universitas Papua, Manokwari \\ wyuliani25@gmail.com \\ Sarah Usman \\ Universitas Papua, Manokwari \\ s.usman@unipa.ac.id \\ Dirarini Sudarwadi \\ Universitas Papua, Manokwari \\ diarinis@gmail.com
}

\begin{abstract}
Abstrak: Analisa Minat Investasi Pasar Modal Pada Mahasiswa di Universitas Papua. Tujuan penelitian untuk menguji seberapa besar pengaruh pengetahuan dan motivasi investasi terhadap minat investasi di Pasar Modal pada mahasiswa FEB UNIPA. Rancangan penelitian secara kuantitatif dengan jenis masalah deskriptif. Populasi penelitian yaitu mahasiswa peserta sosialisasi Pasar Modal. Sampel penelitian sebanyak 76 mahasiswa melalui rumus slovin dari total 323 mahasiswa yang menjadi populasi, diambil dengan teknik Simple Random Sampling. Pengumpulan data menggunakan metode kuesioner. Uji instrumen menggunakan uji validitas dan uji reliabilitas. Teknik analisis data yaitu tabulasi data, analisis statistik deskriptif, dan analisis regresi linier berganda. Hasil analisis menyatakan variabel pengetahuan investasi berpengaruh sebesar 21\%, dan motivasi investasi sebesar 58,3\%. Variabel independen secara simultan mempengaruhi variabel dependen sebesar 57,2\%. Variabel motivasi berperan lebih besar, sehingga Bursa Efek Indonesia perlu memfokuskan pada peningkatan motivasi investasi mahasiswa. Untuk peneliti selanjutnya, sebaiknya menggunakan variabel lain selain dari variabel independen pada penelitian ini.
\end{abstract}

Kata kunci: Pengetahuan, Motivasi, Investasi, Mahasiswa, Papua Barat

Abstract: Analysis of Interest In Capital Markets To The FEB Students In Papua University. This study aims to analyze the degree of effects of the investment knowledge and motivation on investment interest in the Capital Market to the students of FEB UNIPA. Quantitative research design with descriptive problem types. The study population is students participating in Capital Market socialization. The research sample of 76 students through slovin formula from a total of 323 students who became the population, was taken by simple random sampling technique. Data collection using the questionnaire method. The instrument test uses a validity test and a reliability test. Data analysis techniques are data tabulation, descriptive statistical analysis, and multiple linear regression analysis. The results of the study show that the investment knowledge variable effects of $21 \%$, and the investment motivation of $58.3 \%$. The independent variables simultaneously effect the dependent variable by $57.2 \%$. The motivation variable plays a bigger role, so the Indonesia Stock Exchange needs to focus on increasing student investment motivation. For future researchers, it is better to use other variables than the independent variables in this study.:

Keywords: Knowledge, Motivation, Investment, Students, West Papua

\section{PENDAHULUAN}

Perkembangan investasi Pasar Modal di

Papua Barat mengalami kenaikan yang signifikan, hal ini dapat dilihat dari pertumbuhan jumlah investor Pasar Modal 


\section{Nominal: Barometer Riset Akuntansi dan Manajemen}

P-ISSN: 2303-2065 E-ISSN: 2502-5430

Volume 9 No 2 (2020)

di Papua Barat. Papua Barat memiliki kantor perwakilan Bursa Efek Indonesia.

Bursa Efek Indonesia Kantor Perwakilan Papua Barat didirikan pada awal tahun 2017, jumlah investor di Papua Barat mengalami peningkatan yang signifikan. Jumlah investor di Papua Barat mengalami kenaikan yang signifikan yaitu sebesar 52,4\%, hingga akhir tahun 2018 tercatat ada sebanyak 1.509 investor (Bursa Efek Indonesia Kantor Perwakilan Manokwari, 2019). Investor Papua Barat tersebar di beberapa daerah yaitu di Kabupaten Fak Fak, Kabupaten Kaimana, Kabupaten Manokwari, Kabupaten Raja Ampat, Kabupaten Sorong Selatan, Kabupaten Tambrauw, Kabupaten Teluk Bintuni, Kabupaten Teluk Wondama, dan Kota Sorong.

Data penyebaran investor Papua Barat terlihat pada gambar 1 di bawah ini:

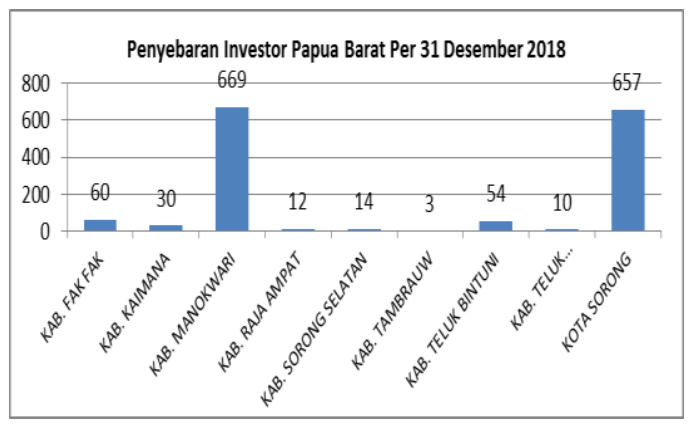

Gambar 1: Diagram Penyebaran Investor Papua Barat

Terlihat pada gambar 1 pertumbuhan jumlah investor yang paling tinggi adalah pada Kabupaten Manokwari. Namun, jika dibandingkan dengan jumlah penduduk Kabupaten Manokwari sebanyak 238.133 jiwa, jumlah investor di Kabupaten Manokwari masih sangat sedikit yaitu hanya sebesar 0,28\% (manokwarikab.go.id, 2019). Pertumbuhan jumlah investor dipengaruhi oleh pengetahuan investasi dan juga motivasi investasi dalam berinvestasi.

Adapun perbandingan jumlah investor di Manokwari dengan jumlah penduduk Kabupaten Manokwari dapat dilihat pada gambar 2 di bawah ini:

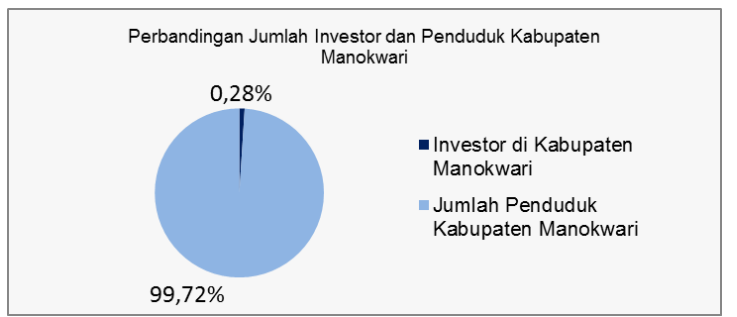

Gambar 2: Diagram Perbandingan Jumlah Investor dan Penduduk Kabupaten Manokwari

Berdasarkan gambar 2 di atas, terlihat perbandingan jumlah investor di Kabupaten Manokwari dengan jumlah penduduk Kabupaten Manokwari yang sangat jauh. Investor di Kabupaten Manokwari hanya sebesar 0,28\%, sedangkan jumlah penduduk Kabupaten Manokwari sebesar 99,72\%. Dalam usaha untuk meningkatkan jumlah investor di Kabupaten Manokwari dan menyadarkan masyarakat tentang pentingnya investasi, maka pihak Bursa Efek Indonesia selalu memberikan sosialisasi kepada masyarakat berupa pengetahuan investasi. 
Menurut Halim (2005), pengetahuan investasi mencakup berbagai aspek mengenai investasi, yaitu tentang jenis-jenis investasi, keuntungan, hingga resiko yang akan dihadapi oleh investor di Pasar Modal. Pengetahuan masyarakat Manokwari mengenai produk dan layanan jasa keuangan yang terkait dengan instrumen investasi keuangan relatif masih rendah. Rendahnya pengetahuan investasi masyarakat Manokwari dapat dilihat dari rendahnya tingkat literasi keuangan di Papua Barat sebesar 19,3\%, yaitu dibawah rata-rata indeks literasi keuangan nasional sebesar $29,7 \%$, dan berada diurutan terakhir dari seluruh provinsi di Indonesia (OJK dalam dokumen SNLKI, 2017). Oleh karena itu literasi keuangan di Papua Barat penting untuk ditingkatkan.

$$
\text { Meningkatkan pengetahuan }
$$

investasi penting untuk meningkatkan minat investasi pada masyarakat Manokwari. Selain pengetahuan investasi, motivasi juga memiliki peran dalam pengambilan keputusan investasi. Sebab tanpa adanya motivasi, maka seseorang tidak akan tergerak untuk melakukan tindakan investasi.

Motivasi adalah suatu kondisi yang mendorong atau menjadi sebab seseorang melakukan suatu perbuatan/kegiatan, yang berlangsung secara sadar. Dari pengertian tersebut berarti pula semua teori motivasi bertolak dari prinsip utama bahwa: "'manusia (seseorang) hanya melakukan suatu kegiatan, yang menyenangkannya untuk dilakukan (Kadir, Abdul \& Machasin, 2014). Motivasi masyarakat Manokwari untuk berinvestasi terbilang rendah. Rendahnya motivasi investasi disebabkan karena rendahnya pemahaman dan pengetahuan masyarakat mengenai investasi di Pasar Modal yang bermanfaat untuk jangka panjang.

Masalah rendahnya motivasi investasi yang disebabkan oleh rendahnya tingkat pengetahuan investasi disampaikan oleh Tito Sulistio, Direktur Utama PT Bursa Efek Indonesia (BEI) bahwa "Motivasi masyarakat Indonesia untuk berinvestasi rendah, karena kurangnya pengetahuan masyarakat Indonesia tentang investasi di Pasar Modal yang dapat menghasilkan keuntungan yang lebih tinggi dibandingkan instrumen investasi lainnya" (Apriyani, 2015). Pengetahuan investasi dan motivasi investasi ternyata penting dalam pembentukan minat berinvestasi.

Minat investasi adalah niat yang terbentuk karena adanya daya gerak berupa pengetahuan investasi dan motivasi investasi yang dimiliki seseorang. Usaha yang dilakukan oleh Bursa Efek Indonesia untuk membentuk minat investasi, selain melalui edukasi kepada masyarakat, edukasi juga diberikan pada perguruan 


\section{Nominal: Barometer Riset Akuntansi dan Manajemen \\ P-ISSN: 2303-2065 E-ISSN: 2502-5430 \\ Volume 9 No 2 (2020)}

tinggi yang ada di Kabupaten Manokwari seperti Universitas Papua dan STIE Mah Eisa. Selain memberikan sosialisasi Pasar Modal, untuk meningkatkan minat berinvestasi pada mahasiswa Universitas Papua, Bursa Efek Indonesia mendirikan Galeri Investasi yang berfungsi untuk memberikan akses bagi mahasiswa untuk lebih mudah mengenal dan langsung berinvestasi di Pasar Modal.

Galeri Investasi di Universitas Papua sering mengadakan edukasi Pasar Modal kepada mahasiswa yang ada di Fakultas Ekonomi dan Bisnis. Namun, edukasi tersebut tidak memberikan hasil yang maksimal dalam meningkatkan minat berinvestasi mahasiswa Fakultas Ekonomi dan Bisnis di Pasar Modal. Hal ini dapat dilihat dari setiap kegiatan yang diselenggarakan hanya memperoleh sedikit investor baru, misalkan dari 100\% yang hadir dalam kegiatan, hanya $5 \%$ yang ingin berinvestasi di Pasar Modal dengan membuka Rekening Dana Investor. Terlihat bahwa minat investasi mahasiswa rendah.

Rendahnya minat investasi di Fakultas Ekonomi dan Bisnis Universitas Papua dapat dilihat dari jumlah investor yang terdaftar di Galeri Investasi yaitu hanya sebanyak 241 investor, sudah termasuk dengan dosen-dosen serta mahasiswa selain Fakultas Ekonomi dan
Bisnis Indonesia (Indonesia, P.S.,2019). Sedangkan jumlah mahasiswa aktif di Fakultas Ekonomi dan Bisnis adalah 1.053 mahasiswa (Data Kemahasiswaan FEB UNIPA, 2019). Jika di persentasekan, pertumbuhan jumlah investor yang terdaftar di Galeri Investasi dari tahun 2017 hingga tahun 2019 hanya sebesar 22,8\%. Jika diukur dari tahun 2017 hingga saat ini tahun 2019, jumlah investor masih sangat sedikit. Adapun jumlah investor yang terdaftar di Galeri Investasi Universitas Papua dapat terlihat pada tabel 1 di bawah ini:

Tabel 1: Perbandingan Jumlah Investor di Galeri Investasi Universitas Papua

\begin{tabular}{lc}
\hline Kategori & \multicolumn{1}{l}{$\begin{array}{l}\text { Tahun } \\
\mathbf{2 0 1 7 - 2 0 1 9}\end{array}$} \\
\hline Mahasiswa & Fakultas $\quad$ Ekonomi \\
dan Bisnis & 221 \\
Mahasiswa Fakultas Lain & 12 \\
Jumlah & $\mathbf{2 4 1}$ \\
\hline Sumber: Phillip Sekuritas Indonesia 2019
\end{tabular}

Berdasarkan tabel 1, terlihat bahwa jumlah investor yang paling banyak yaitu pada mahasiswa Fakultas Ekonomi dan Bisnis sebanyak 221 mahasiswa, tetapi jumlah mahasiswa aktif Fakultas Ekonomi dan Bisnis ada 1.053 mahasiswa. Penyebab dari rendahnya jumlah investor pada mahasiswa Fakultas Ekonomi dan Bisnis diduga oleh kurangnya pengetahuan yang dimiliki mahasiswa terkait investasi di Pasar Modal. Padahal, Bursa Efek Indonesia sudah cukup sering mengadakan 


\section{Nominal: Barometer Riset Akuntansi dan Manajemen}

P-ISSN: 2303-2065 E-ISSN: 2502-5430

Volume 9 No 2 (2020)

sosialisasi Pasar Modal. Selain kurangnya pengetahuan investasi, diduga mahasiswa Fakultas Ekonomi dan Bisnis kurang berminat pada investasi di Pasar Modal.

Permasalahan tersebut membuat peneliti tertarik untuk melakukan penelitian pada mahasiswa Fakultas Ekonomi dan Bisnis yang telah mendapatkan sosialisasi Pasar Modal dari Bursa Efek Indonesia maupun Galeri Investasi karena mahasiswa Fakultas Ekonomi dan Bisnis Universitas Papua telah mendapatkan pengetahuan tentang investasi.

\section{KAJIAN LITERATUR}

Penelitian serupa pernah dilakukan oleh beberapa orang, yaitu diantaranya:

Pengaruh Motivasi Investasi dan Pengetahuan Investasi Terhadap Minat Investasi Di Pasar Modal Pada Mahasiswa FE UNY. Hasil penelitian Motivasi investasi (X1) berpengaruh terhadap minat berinvestasi (Y). Pengetahuan investasi (X2) berpengaruh terhadap minat berinvestasi (Y). Motivasi (X1) dan pengetahuan investasi (X2) secara simultan berpengaruh terhadap minat berinvestasi (Y). (Pajar R. C., 2017)

Judul Pengaruh Motivasi Terhadap Minat Berinvestasi di Pasar Modal dengan Pemahaman Investasi dan Usia Sebagai Variabel Moderat. Hasil penelitian Motivasi (XI) berpengaruh positif terhadap minat berinvestasi (Y) dengan minat investasi wanita dan usia sebagai variabel moderat. (Situmorang, 2014)

Pengaruh Sosialisasi dan Pengetahuan pada Minat Investor Pada Efek Syariah di Pasar Modal (Survei Pada Nasabah PT Danareksa Sekuritas Cabang FE- UI Depok). Hasil penelitian Sosialisasi (X1) berpengaruh signifikan terhadap minat investor (Y). Pengetahuan (X2) berpengaruh signifikan terhadap minat investor (Y). (Khotimah et al., 2011) Kajian teori terhadap variable penelitian minat menurut Amhalmad \& Irianto, (2019) terkait pada rasa manusia yaitu rasa lebih suka dan rasa keterikatan pada suatu hal atau aktivitas, tanpa ada yang menyuruh.

Minat adalah suatu kecenderungan untuk memberikan perhatian dan bertindak terhadap orang, aktivitas, atau situasi yang menjadi objek dari minat tersebut dengan disertai perasaan senang. (Firyanti \& Oktafani, 2015)

Berdasarkan definisi di atas, dapat disimpulkan bahwa minat adalah kecenderungan ingin memberikan perhatian pada objek minat dengan perasaan senang secara konsisten tanpa ada yang menyuruh.

Sehingga minat investasi adalah perasaan ingin memberikan perhatian kepada kegiatan investasi atau ingin 
dilibatkan untuk mengetahui lebih banyak tentang kegiatan investasi.

Jika dikaitkan antar variable, maka pola pemikiran penelitian sebagai berikut:

\section{Pengaruh Pengetahuan Investasi}

\section{Terhadap Minat Investasi}

Investasi adalah penanaman modal untuk satu ataupun lebih aktiva yang dimiliki dan juga biasanya berjangka waktu lama dengan harapan untuk mendapatkan keuntungan di masa-masa yang akan datang (Situmorang, 2014). Sedangkan, Pengetahuan investasi adalah hasil tahu seseorang dari proses pembelajaran tentang investasi. Pengetahuan investasi merupakan salah satu aspek yang penting sebelum melakukan investasi agar mendapatkan keuntungan dan terhindar dari risiko di masa depan. Pengetahuan investasi yang dimiliki mahasiswa Universitas Papua Fakultas Ekonomi dan Bisnis sudah cukup baik, sehingga tertarik untuk mengenal investasi lebih jauh. Ketertarikan mahasiswa Universitas Papua Fakultas Ekonomi dan Bisnis dapat dilihat dari keikutsertaan mereka pada kegiatankegiatan yang diselenggarakan Bursa Efek Indonesia berupa Sosialisasi Pasar Modal.

Dari kegiatan tersebut mahasiswa memperoleh pengetahuan investasi berupa jenis-jenis investasi, keuntungan, serta risiko investasi. Mempertegas hal ini, Khotimah et al.,(2011) mengatakan bahwa pengetahuan akan mempengaruhi keputusan pembelian, ketika konsumen memiliki pengetahuan yang lebih banyak, maka ia akan lebih baik dalam mengambil keputusan, ia akan lebih efisien dan lebih tepat dalam mengelola informasi. Pengetahuan investasi yang diperoleh melalui sosialisasi Pasar Modal disikapi dengan cukup antusias yang terlihat melalui pertanyaan-pertanyaan yang diajukan mahasiswa kepada Bursa Efek Indonesia tentang Pasar Modal.

Pengetahuan investasi yang dimiliki mahasiswa Universitas Papua Fakultas Ekonomi dan Bisnis tersebut mempengaruhi minat mereka untuk berinvestasi. Hal ini diperkuat dengan hasil penelitian terdahulu yang dilakukan oleh (Pajar C. , 2017) yang menunjukkan bahwa terdapat pengaruh pada pengetahuan investasi terhadap minat berinvestasi di Pasar Modal.

\section{Pengaruh Motivasi Investasi Terhadap} Minat Investasi

Menurut Firyanti \& Oktafani (2015) motivasi adalah proses pemberian dorongan yang dapat menentukan intensitas, arah, dan ketekunan individu dalam usaha mencapai sasaran serta berpengaruh secara langsung terhadap tugas dan psikologi seseorang, sehingga dalam menentukan tindakan yang akan 
Nominal: Barometer Riset Akuntansi dan Manajemen

P-ISSN: 2303-2065 E-ISSN: 2502-5430

Volume 9 No 2 (2020)

diambil seseorang didasari atas

kebutuhannya.

Teori Herzberg teori dua faktor (two-factor theory) juga disebut teori motivasi hygiene (motivation-hygiene theory). Motivasi intrinsik, ialah motivasi yang berasal dari diri seseorang itu sendiri tanpa dirangsang dari luar dan Motivasi ekstrinsik, yaitu motivasi yang datang karena adanya rangsangan dari luar (Krisnangningsih, 2019).

Motivasi yang dimiliki mahasiswa Universitas Papua Fakultas Ekonomi dan Bisnis berasal dari dalam diri dan juga pengaruh dari luar. Motivasi intrinsik mahasiswa terlihat ketika mahasiswa datang dengan keinginan sendiri untuk mengunjungi Galeri Investasi untuk memperoleh informasi yang diinginkan tentang investasi di Pasar Modal.

Selain itu, ada motivasi ekstrinsik mahasiwa untuk mengenal tentang investasi yang diperoleh dari orang lain yang telah mengenal investasi lebih dulu, dan pihak-pihak kampus seperti Galeri Investasi dan dosen yang mengajak untuk mengikuti kegiatan sosialisasi Pasar Modal.

Adanya berbagai pengaruh dari luar, membuat mereka tertarik untuk mengenal tentang investasi di Pasar Modal. Motivasi dari luar berupa ajakan dari dosen untuk mengikuti sosialisasi Pasar Modal disambut cukup antusias. Ketertarikan

tersebut nantinya akan berubah menjadi keputusan untuk berinvestasi di Pasar Modal. Oleh karena itu, dapat disimpulkan bahwa motivasi berpengaruh pada minat investasi. Hal ini diperkuat dengan hasil penelitian terdahulu yang dilakukan oleh ). (Pajar R. C., 2017)

yang menunjukkan bahwa terdapat pengaruh pada motivasi investasi terhadap minat berinvestasi di Pasar Modal.

Pengaruh Pengetahuan Investasi dan Motivasi Investasi Secara Bersama-sama Terhadap Minat Investasi

Pengetahuan yang cukup mengenai investasi dapat menunjang keberhasilan seseorang dalam berinvestasi. Pengetahuan yang memadai akan suatu hal dapat memberikan motivasi seseorang untuk mengambil keputusan atau melakukan suatu tindakan. Seseorang yang termotivasi untuk melakukan investasi cenderung akan berusaha untuk mencari berbagai pengetahuan yang berkaitan dengan investasi dan minat investasi yang dimiliki semakin meningkat.

Pengetahuan investasi yang dimiliki mahasiswa Universitas Papua Fakultas Ekonomi dan Bisnis berupa jenis-jenis investasi, keuntungan, serta risiko, dan motivasi yang dimiliki baik motivasi intrinsik maupun ekstrinsik secara simultan mempengaruhi minat mereka untuk berinvestasi di Pasar Modal. Kedua 
pengaruh ini dapat terlihat dari beberapa mahasiswa yang datang ke Galeri Investasi untuk mengenal lebih dalam tentang investasi di Pasar Modal. Mereka datang ke Galeri Investasi karena mengetahui informasi dari teman-teman yang sudah mengenal Pasar Modal lebih dulu, sehingga mereka tertarik/minat untuk mengenal lebih dalam investasi di Pasar Modal. Hal ini diperkuat dengan hasil penelitian terdahulu yang dilakukan oleh (Pajar R. C., 2017) yang menunjukkan bahwa terdapat pengaruh pada motivasi investasi dan pengetahuan investasi terhadap minat berinvestasi di Pasar Modal.

Gambaran keterkaitan variabel pengetahuan dan motivasi dasar teori dalam penelitian ini berdasarkan dasar pemikiran penelitian dibawah ini:

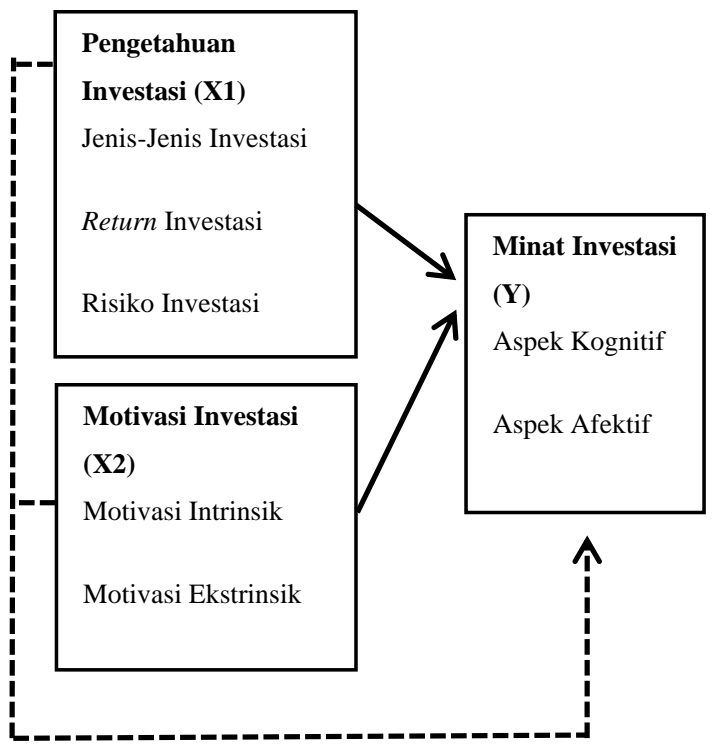

Gambar 3: Kerangka Pemikiran Teoritis

\section{METODE PENELITIAN}

Jenis masalah penelitian dalam penelitian ini yaitu deskriptif dengan metode pendekatan kuantitatif.

Populasi adalah seluruh mahasiswa aktif Fakultas Ekonomi dan Bisnis Universitas Papua peserta sosialisasi Pasar Modal sebanyak 323 mahasiswa (Galeri Investasi Universitas Papua, 2019).

Metode sampling pada penelitian ini menggunakan Probability Sampling (Sugiyono, 2017). Teknik yang digunakan dalam pengambilan sampel yakni menggunakan metode Simple Random Sampling (Sugiyono, 2017). Adapun penetapan ukuran sampel dengan menggunakan rumus slovin sebagai berikut:

$$
\mathrm{n}=\frac{N}{1+N(e)^{2}}
$$

Dimana:

$\mathrm{n}=$ ukuran sampel

$\mathrm{N}=$ populasi

$\mathrm{e}=$ tingkat kesalahan $/$ error $10 \%(0,1)$

$\mathrm{n}=\frac{323}{1+323(0,1)^{2}}$

$\mathrm{n}=\frac{323}{4,23} \mathrm{n}=76,359$ dibulatkan menjadi 76 responden

Teknik pengumpulan data menggunakan metode dokumentasi yaitu pendokumentasian data fisik berupa absensi peserta sosialisasi Pasar Modal dan 


\section{Nominal: Barometer Riset Akuntansi dan Manajemen}

P-ISSN: 2303-2065 E-ISSN: 2502-5430

Volume 9 No 2 (2020)

kuesioner yang dibagikan kepada mahasiswa FEB UNIPA.

Metode dan teknik analisis data yang digunakan yaitu tabulasi data, analisisi statistik deskriptif, dan analisis regresi linear berganda. Analisis deskriptif adalah statistik yang digunakan untuk menganalisa data dengan cara mendeskriptifkan atau menggambarkan data yang telah terkumpul sebagaimana adanya (Sugiyono, 2017). Analisa deskriptif dihitung nilai min, max dan average dari jawaban yang ditanyakan.

Alat analisa kedua yaitu regresi linear berganda. Menurut (Ghozali 2011), analisis regresi linear berganda dilakukan untuk menguji pengaruh dua atau lebih variabel independen terhadap suatu variabel dependen.

Model regresi linear berganda dalam penelitian ini ditunjukan dengan persamaan sebagai berikut:

$\mathbf{Y}=\alpha+\boldsymbol{\beta}_{1} \mathbf{X}_{1}+\boldsymbol{\beta}_{2} \mathbf{X}_{2}+e$

Keterangan:

Y : Minat Investasi

$\alpha \quad$ : Konstanta

$\beta \quad$ : Koefisien Regresi

$\mathrm{X}_{1} \quad$ : Pengetahuan Investasi

$\mathrm{X}_{2} \quad$ : Motivasi Investasi

e : Tingkat error, tingkat kesalahan

Uji instrumen penelitian yang digunakan dalam penelitian ini yaitu uji validitas dan uji reliabilitas. Uji validitas digunakan untuk mengukur sah atau valid tidaknya suatu kuesioner, kuesioner dikatakan valid jika mampu mengungkapkan sesuatu yang akan diukur. Syarat yang harus dipenuhi, jika $r>0,05$ maka item-item tersebut dinyatakan valid. Suatu kuesioner dikatakan reliabel atau handal jika jawaban seseorang terhadap pernyataan adalah konsisten atau stabil dari waktu ke waktu. Variabel reliabel atau handal apabila mempunyai nilai Cronbach Alpha > 0,60 (Ghozali, 2011).

Uji asumsi klasik yang digunakan dalam penelitian ini yaitu uji normalitas, uji heteroskedastisitas, dan uji multikolinearitas. Untuk menguji apakah data terdistribusi normal atau tidak, dilakukan uji statistik KolmogorovSmirnov Test, berdistribusi normal jika memiliki nilai signifikan > 0,05 (Ghozali, 2011). Uji heteroskedastisitas menunjukkan bahwa variansi variabel tidak sama untuk semua pengamatan. Untuk menguji uji statistik Gletser SPSS, jika signifikansi > dari 0,05 maka dapat disimpulkan tidak terjadi heteroskedastisitas (Ghozali, 2011). Uji multikolinieritas bertujuan untuk menguji apakah model regresi ditemukan adanya kolerasi antar variabel bebas. Untuk menguji multikolinieritas dengan cara melihat VIF (Variance Inflation Factor) masing-masing variabel independen. Jika 


\section{Nominal: Barometer Riset Akuntansi dan Manajemen}

P-ISSN: 2303-2065 E-ISSN: 2502-5430

Volume 9 No 2 (2020)

nilai VIF < 10 atau jika nilai tolerance > 0,10 maka tidak ada multikolinieritas dalam model regresi.

Pengujian hipotesis dalam penelitian ini menggunakan uji koefisien determinasi, uji simultan (uji F) dan uji parsial (uji t). Koefisien determinasi $\left(R^{2}\right)$ mengukur seberapa jauh kemampuan model menerangkan variasi variabel dependen. Nilai koefisien determinasi adalah $0<\mathrm{R}^{2}<1$ (Ghozali, 2011). Menurut (Ghozali, 2011) uji Statistik F menunjukkan apakah semua variabel independen atau variabel bebas yang dimasukkan dalam model mempunyai pengaruh secara simultan terhadap variabel dependen. Jika signifikansi $<0,05$ maka hipotesis diterima. Menurut (Ghozali, 2011) menyatakan bahwa untuk menguji hubungan masing-masing variabel bebas terhadap variabel terikat secara parsial atau per variabel digunakan uji t, menunjukkan seberapa jauh pengaruh satu variabel bebas secara individual dalam menerangkan variasi variabel terikat. Apabila nilai thitung $>$ tabel, maka variabel bebas secara terpisah memberi pengaruh terhadap variabel terikat.

\section{HASIL PENELITIAN DAN}

PEMBAHASAN

Hasil analisis diperoleh nilai $r-$ hitung > r-tabel yaitu 0,225. Sehingga dapat disimpulkan bahwa seluruh pernyataan yang terdapat di dalam kuesioner penelitian dinyatakan valid. Terlihat pada table 2

Tabel 2: Hasil Uji Validitas

\begin{tabular}{|c|c|c|c|}
\hline Variabel & $\begin{array}{l}\text { Pernyataa } \\
\text { n }\end{array}$ & $\begin{array}{l}\mathbf{r} \\
\text { hitung }\end{array}$ & $\begin{array}{l}\text { Keteranga } \\
\text { n }\end{array}$ \\
\hline $\begin{array}{l}\text { Pengetahua } \\
\text { n Investasi } \\
\text { (X1) }\end{array}$ & $\begin{array}{l}\text { A1.1 } \\
\text { A1.2 } \\
\text { A1.3 } \\
\text { A1.4 } \\
\text { A1.5 } \\
\text { A1.6 } \\
\text { A1.7 } \\
\text { A1.8 } \\
\text { A1.9 } \\
\text { A2.1 } \\
\text { A2.2 } \\
\text { A2.3 } \\
\text { A2.4 } \\
\text { A2.5 } \\
\text { A2.6 } \\
\text { A3.1 } \\
\text { A3.2 } \\
\text { A3.3 } \\
\text { A3.4 } \\
\text { A3.5 } \\
\text { A3.6 }\end{array}$ & $\begin{array}{l}0,690 \\
0,562 \\
0,393 \\
0,721 \\
0,436 \\
0,462 \\
0,459 \\
0,566 \\
0,642 \\
0,518 \\
0,420 \\
0,623 \\
0,529 \\
0,657 \\
0,608 \\
0,426 \\
0,581 \\
0,633 \\
0,514 \\
0,557 \\
0,584\end{array}$ & $\begin{array}{l}\text { Valid } \\
\text { Valid } \\
\text { Valid } \\
\text { Valid } \\
\text { Valid } \\
\text { Valid } \\
\text { Valid } \\
\text { Valid } \\
\text { Valid } \\
\text { Valid } \\
\text { Valid } \\
\text { Valid } \\
\text { Valid } \\
\text { Valid } \\
\text { Valid } \\
\text { Valid } \\
\text { Valid } \\
\text { Valid } \\
\text { Valid } \\
\text { Valid } \\
\text { Valid }\end{array}$ \\
\hline $\begin{array}{l}\text { Motivasi } \\
\text { Investasi } \\
(\mathrm{X} 2)\end{array}$ & $\begin{array}{l}\text { B1.1 } \\
\text { B1.2 } \\
\text { B1.3 } \\
\text { B1.4 } \\
\text { B1.5 } \\
\text { B2.1 } \\
\text { B2.2 } \\
\text { B2.3 } \\
\text { B2.4 } \\
\text { B2.5 } \\
\end{array}$ & $\begin{array}{l}0,696 \\
0,610 \\
0,448 \\
0,550 \\
0,395 \\
0,696 \\
0,565 \\
0,483 \\
0,663 \\
0,454 \\
\end{array}$ & $\begin{array}{l}\text { Valid } \\
\text { Valid } \\
\text { Valid } \\
\text { Valid } \\
\text { Valid } \\
\text { Valid } \\
\text { Valid } \\
\text { Valid } \\
\text { Valid } \\
\text { Valid } \\
\end{array}$ \\
\hline $\begin{array}{l}\text { Minat } \\
\text { Investasi } \\
\text { (Y) }\end{array}$ & $\begin{array}{l}\mathrm{C} 1.1 \\
\mathrm{C} 1.2 \\
\mathrm{C} 1.3 \\
\mathrm{C} 1.4 \\
\mathrm{C} 1.5 \\
\mathrm{C} 2.1 \\
\mathrm{C} 2.2 \\
\mathrm{C} 2.3 \\
\mathrm{C} 2.4 \\
\mathrm{C} 2.5\end{array}$ & $\begin{array}{l}0,666 \\
0,783 \\
0,640 \\
0,625 \\
0,617 \\
0,727 \\
0,650 \\
0,674 \\
0,496 \\
0,637\end{array}$ & $\begin{array}{l}\text { Valid } \\
\text { Valid } \\
\text { Valid } \\
\text { Valid } \\
\text { Valid } \\
\text { Valid } \\
\text { Valid } \\
\text { Valid } \\
\text { Valid } \\
\text { Valid }\end{array}$ \\
\hline
\end{tabular}

Sumber : Data primer yang diolah 2019 
Nilai Cronbach Alpha ( $\alpha$ ) dari masing-masing variabel $>0,60$. Dengan demikian dapat dinyatakan bahwa seluruh butir pernyataan yang digunakan pada penelitian ini adalah reliabel.

Berdasarkan tabel 4, diperoleh nilai signifikan sebesar $0,200(0,200>0,05)$. Dengan demikian dapat dinyatakan bahwa seluruh butir pernyataan yang digunakan pada penelitian ini terdistribusi normal.

Tabel 3: Hasil Uji Reliabilitas

\begin{tabular}{lll}
\hline Variabel & $\begin{array}{l}\text { Cronbach } \\
\text { Alpha }(\boldsymbol{\alpha})\end{array}$ & Keterangan \\
\hline $\begin{array}{l}\text { Pengetahuan } \\
\text { Investasi (X1) }\end{array}$ & 0,878 & Reliabel \\
$\begin{array}{l}\text { Motivasi } \\
\text { Investasi (X2) }\end{array}$ & 0,745 & Reliabel \\
$\begin{array}{l}\text { Minat Investasi } \\
\text { (Y) }\end{array}$ & 0,840 & Reliabel \\
\hline
\end{tabular}

Sumber : Data primer yang diolah 2019

Tabel 4. One-Sample KolmogorovSmirnov Test

\begin{tabular}{|c|c|c|}
\hline & & $\begin{array}{l}\text { Unstandardized } \\
\text { Residual }\end{array}$ \\
\hline $\mathrm{N}$ & & 76 \\
\hline Normal & Mean & .0000000 \\
\hline Parameters ${ }^{\mathrm{a}, \mathrm{b}}$ & Std. Deviation & 1.78531818 \\
\hline Most & Absolute & .065 \\
\hline Extreme & Positive & .065 \\
\hline Differences & Negative & -.061 \\
\hline Test Statistic & & .065 \\
\hline Asymp. Sig. & (2-tailed) & $.200^{\mathrm{c}, \mathrm{d}}$ \\
\hline
\end{tabular}

Selanjutnya terlihat bahwa hasil uji heteroskedastisitas bahwa nilai signifikan variabel pengetahuan investasi (X1) sebesar $0,088(0,088>0,05)$ dan variabel motivasi investasi (X2) sebesar 0,206 $(0,206>0,05)$.

Tabel 5: Hasil Uji Heterokedastisitas

\begin{tabular}{llll}
\hline Variabel & Sig. & Keterangan \\
\hline $\begin{array}{l}\text { Pengetahuan } \\
\text { Investasi }\end{array}$ & 0,088 & $\begin{array}{l}\text { Tidak terjadi } \\
\text { heteroskedastisitas }\end{array}$ \\
$\begin{array}{l}\text { Motivasi } \\
\text { Investasi }\end{array}$ & 0,206 & $\begin{array}{l}\text { Tidak } \\
\text { heteroskedastisitas }\end{array}$ \\
\hline
\end{tabular}

Sumber : Data primer yang diolah 2019

Dari tabel 6, diketahui nilai tolerance dari variabel pengetahuan investasi (X1) sebesar 0,800 $(0,800>0,10)$, variabel motivasi investasi (X2) sebesar $0,800(0,800>0,10)$. Nilai VIF dari variabel pengetahuan investasi (X1) 1,251 $(1,251<10)$, variabel motivasi investasi (X2) $1,251(1,251<10)$. Artinya tidak ada multikolinearitas atas variabel independen pada model regresi.

Tabel 6: Hasil Uji Multikolinearitas

\begin{tabular}{|c|c|c|c|c|c|c|}
\hline \multirow[t]{2}{*}{ Model } & \multicolumn{2}{|c|}{$\begin{array}{l}\text { Unstandar } \\
\text { dized } \\
\text { Coefficien } \\
\text { ts }\end{array}$} & \multicolumn{3}{|c|}{$\begin{array}{l}\text { Standar } \\
\text { dized } \\
\text { Coeffici } \\
\text { ents }\end{array}$} & $\begin{array}{l}\text { Colli } \\
\text { neari } \\
\text { ty } \\
\text { Stati }\end{array}$ \\
\hline & B & $\begin{array}{l}\text { Std. } \\
\text { Erro } \\
\mathrm{r}\end{array}$ & Beta & $\mathrm{t}$ & sig & $\begin{array}{l}\text { Toler } \\
\text { ance }\end{array}$ \\
\hline (Constan & .529 & $\begin{array}{l}1.69 \\
9\end{array}$ & & $\begin{array}{l}.31 \\
2\end{array}$ & .75 & \\
\hline $\begin{array}{l}\text { Pengeta } \\
\text { huan } \\
\text { Investas } \\
\text { i (X1) }\end{array}$ & 210 & .047 & .386 & $\begin{array}{l}4.5 \\
13\end{array}$ & $\begin{array}{l}.00 \\
0\end{array}$ & .800 \\
\hline $\begin{array}{l}\text { Motivas } \\
\text { i } \\
\text { Investas } \\
\text { i (X2) }\end{array}$ & .583 & .100 & .500 & $\begin{array}{l}5.8 \\
41\end{array}$ & $\begin{array}{l}.00 \\
0\end{array}$ & .800 \\
\hline
\end{tabular}

Sumber : Data primer yang diolah 2019 
Berdasarkan tabel 7 diperoleh persamaan regresi sebagai berikut:

$Y=0,529+0,210 X 1+0,583 X 2$

Berdasarkan data diatas diperoleh hasil pengujian hipotesis secara parsial (uji t) sebagai berikut:

Pengetahuan Investasi (X1). Variabel pengetahuan investasi (X1) secara parsial berpengaruh terhadap variabel terikat (dependen) yaitu variabel minat investasi (Y).

Motivasi Investasi (X2). Variabel motivasi investasi (X2) secara parsial berpengaruh terhadap variabel terikat (dependen) yaitu variabel minat investasi (Y).

Tabel 7: Hasil Uji Analisis Regresi Linear Berganda

\begin{tabular}{|c|c|c|c|c|c|c|c|}
\hline Model & $\begin{array}{l}\text { Uns } \\
\text { ardi } \\
\text { Coe } \\
\text { ents }\end{array}$ & $\begin{array}{l}\text { stand } \\
\text { ized } \\
\text { effici } \\
\text { s }\end{array}$ & $\begin{array}{l}\text { Standa } \\
\text { rdized } \\
\text { Coeffic } \\
\text { ients }\end{array}$ & $\mathrm{t}$ & & $\begin{array}{l}\text { Colli } \\
\text { rity } \\
\text { Stati } \\
\text { S } \\
\end{array}$ & nea \\
\hline & B & $\begin{array}{l}\text { Std. } \\
\text { Erro } \\
\mathrm{r}\end{array}$ & Beta & & & $\begin{array}{l}\text { Tol } \\
\text { eran } \\
\text { ce }\end{array}$ & $\begin{array}{l}\text { VI } \\
\text { F }\end{array}$ \\
\hline (Consta & .5 & 1.69 & & .3 & .75 & & \\
\hline nt) & 29 & 9 & & 12 & 6 & & \\
\hline $\begin{array}{l}\text { Penget } \\
\text { ahuan }\end{array}$ & $\begin{array}{l}.2 \\
10\end{array}$ & .047 & .386 & $\begin{array}{l}4 . \\
51\end{array}$ & $\begin{array}{l}.00 \\
0\end{array}$ & .800 & $\begin{array}{l}1 . \\
25\end{array}$ \\
\hline $\begin{array}{l}\text { Investa } \\
\text { si (X1) }\end{array}$ & & & & 3 & & & 1 \\
\hline $\begin{array}{l}\text { Motiva } \\
\text { si }\end{array}$ & $\begin{array}{l}.5 \\
83\end{array}$ & .100 & .500 & 8. & $\begin{array}{l}.00 \\
0\end{array}$ & .800 & 1. \\
\hline $\begin{array}{l}\text { Investa } \\
\text { si (X2) }\end{array}$ & & & & 1 & & & 1 \\
\hline
\end{tabular}

a. Dependent Variable: Minat Investasi (Y) Sumber : Data primer yang diolah 2019

Adapun hasil uji analisis deskriptif statistik dapat dilihat pada tabel 8.Adapun penjelasan mengenai hasil perhitungan statistik diuraikan sebagai berikut:
Tabel 8: Analisa Deskriptif

\begin{tabular}{|c|c|c|c|c|}
\hline & $\mathbf{N}$ & Min & Max & Mean \\
\hline \multicolumn{5}{|c|}{ Pengetahuan Investasi (X1) } \\
\hline $\begin{array}{l}\text { Jenis- } \\
\text { Investasi }\end{array}$ & Jenis 76 & $\begin{array}{l}50 \\
\text { (item } \\
3 \& 8 \text { ) }\end{array}$ & $\begin{array}{l}68 \\
\text { (item 4) }\end{array}$ & $\begin{array}{l}58 \\
\text { (item } \\
1 \text { ) }\end{array}$ \\
\hline $\begin{array}{l}\text { Return } \\
\text { Investasi }\end{array}$ & 76 & $\begin{array}{l}38 \\
\text { (item } \\
3 \text { ) }\end{array}$ & $\begin{array}{l}67 \\
\text { (item } \\
1 \& 5)\end{array}$ & $\begin{array}{l}54 \\
\text { (item } \\
6 \text { ) }\end{array}$ \\
\hline $\begin{array}{l}\text { Risiko } \\
\text { Investasi }\end{array}$ & 76 & $\begin{array}{l}31 \\
\text { (item } \\
2 \text { ) }\end{array}$ & $\begin{array}{l}53 \\
\text { (item 5) }\end{array}$ & $\begin{array}{l}44 \\
\text { (item } \\
4 \text { ) }\end{array}$ \\
\hline \multicolumn{5}{|c|}{ Motivasi Investasi (X2) } \\
\hline $\begin{array}{l}\text { Motivasi } \\
\text { Intrinsik }\end{array}$ & $\begin{array}{l}7 \\
6\end{array}$ & $\begin{array}{l}25 \\
\text { (item } \\
5)\end{array}$ & $\begin{array}{l}67 \\
\text { (item } \\
4 \text { ) }\end{array}$ & $\begin{array}{l}\text { 53,8 } \\
\text { (ite } \\
\text { m 2) }\end{array}$ \\
\hline $\begin{array}{l}\text { Motivasi } \\
\text { Ekstrinsik }\end{array}$ & $\begin{array}{l}7 \\
6\end{array}$ & $\begin{array}{l}10 \\
\text { (item } \\
5 \text { ) }\end{array}$ & $\begin{array}{l}60 \\
\text { (item } \\
3 \text { ) }\end{array}$ & $\begin{array}{l}29,6 \\
\text { (ite } \\
\text { m 4) }\end{array}$ \\
\hline \multicolumn{5}{|c|}{ Minat Investasi $(\mathrm{Y})$} \\
\hline $\begin{array}{l}\text { Aspek } \\
\text { Kognitif }\end{array}$ & $\begin{array}{l}7 \\
6\end{array}$ & $\begin{array}{l}37 \\
\text { (item } \\
5)\end{array}$ & $\begin{array}{l}67 \\
\text { (item } \\
1)\end{array}$ & $\begin{array}{l}55,8 \\
\text { (ite } \\
\text { m 2) }\end{array}$ \\
\hline $\begin{array}{l}\text { Aspek } \\
\text { Afektif }\end{array}$ & $\begin{array}{l}7 \\
6\end{array}$ & $\begin{array}{l}27 \\
\text { (item } \\
4 \text { ) } \\
\end{array}$ & $\begin{array}{l}66 \\
\text { (item } \\
5 \text { ) } \\
\end{array}$ & $\begin{array}{l}51,2 \\
\text { (ite } \\
\text { m 1) }\end{array}$ \\
\hline
\end{tabular}

Pengetahuan Investasi (X1). Hasil pengujian statistik deskriptif, pengetahuan mahasiswa Fakultas Ekonomi dan Bisnis Universitas Papua tentang jenis-jenis investasi dengan nilai maksimum sebesar 68 pada item 4 , artinya pengetahuan tentang jenis-jenis investasi yang paling diketahui mahasiswa adalah tentang investasi saham. Nilai minimum sebesar 50 pada item 3 dan 8 , artinya pengetahuan tentang jenis-jenis investasi yang kurang diketahui mahasiswa adalah tentang investasi emas dan cara transaksi saham melalui aplikasi. Nilai mean sebesar 58 pada item 1, artinya pengetahuan investasi tentang jenis-jenis 


\section{Nominal: Barometer Riset Akuntansi dan Manajemen}

P-ISSN: 2303-2065 E-ISSN: 2502-5430

Volume 9 No 2 (2020)

investasi yang rata-rata diketahui oleh mahasiswa adalah tentang real investment. Hasil pengujian statistik deskriptif, pengetahuan mahasiswa Fakultas Ekonomi dan Bisnis Universitas Papua tentang return investasi dengan nilai maksimum sebesar 67 pada item 1 dan 5, artinya pengetahuan tentang return investasi yang paling diketahui adalah tentang keuntungan dapat meningkatkan nilai uang di masa depan dan keuntungan investasi di Pasar Modal. Nilai minimum sebesar 38 pada item 3 , artinya pengetahuan tentang return investasi yang kurang diketahui mahasiswa adalah tentang yield / imbal hasil. Nilai mean sebesar 54 pada item 6 , artinya pengetahuan investasi tentang return investasi yang rata-rata diketahui oleh mahasiswa adalah tentang pemahaman cara memperoleh keuntungan pada investasi saham.

Hasil pengujian statistik deskriptif, pengetahuan mahasiswa Fakultas Ekonomi dan Bisnis Universitas Papua tentang risiko investasi dengan nilai maksimum sebesar 53 pada item 5 , artinya pengetahuan tentang risiko investasi yang paling diketahui adalah tentang perubahan harga saham diakibatkan oleh permintaan dan penawaran saham. Nilai minimum sebesar 31 pada item 2 , artinya pengetahuan tentang risiko investasi yang kurang diketahui mahasiswa adalah tentang capital loss. Nilai mean sebesar 44 pada item 4, artinya pengetahuan investasi tentang risiko investasi yang rata-rata diketahui oleh mahasiswa adalah tentang likuiditas asset.

Motivasi Investasi (X2). Hasil pengujian statistik deskriptif, motivasi mahasiswa Fakultas Ekonomi dan Bisnis Universitas Papua secara intrinsik dengan nilai maksimum sebesar 67 pada item 4, artinya motivasi intrinsik terbesar yang dimiliki mahasiswa adalah ingin mempersiapkan masa depan. Nilai minimum sebesar 25 pada item 5, artinya motivasi intrinsik terkecil yang dimiliki mahasiswa adalah ingin mendapatkan perasaan berharga dari teman-teman. Nilai mean sebesar 53,8 pada item 2 , artinya motivasi intrinsik yang ratarata dimiliki mahasiswa adalah ingin mendapatkan penghasilan tambahan.

Hasil pengujian statistik deskriptif, motivasi mahasiswa Fakultas Ekonomi dan Bisnis Universitas Papua secara ekstrinsik dengan nilai maksimum sebesar 60 pada item 3, artinya motivasi ekstrinsik terbesar yang dimiliki mahasiswa adalah telah mengikuti sosialisasi Pasar Modal. Nilai minimum sebesar 10 pada item 5 , artinya motivasi ekstrinsik terkecil yang dimiliki mahasiswa adalah karena melihat iklan di TV. Nilai mean sebesar 29,6 pada item 4, artinya motivasi ekstrinsik yang rata-rata dimiliki mahasiswa adalah karena investasi saham lagi nge-trend. 
Minat Investasi (Y). Hasil pengujian statistik deskriptif, minat mahasiswa Fakultas Ekonomi dan Bisnis Universitas Papua untuk berinvestasi dilihat dari aspek kognitif dengan nilai maksimum yaitu sebesar 67 pada item 1, artinya mahasiswa ingin berinvestasi karena mendapatkan pengetahuan tentang Pasar Modal. Nilai minimum sebesar 37 pada item 5, artinya mahasiswa ingin berinvestasi karena mendapatkan pengetahuan tentang diversifikasi saham sebagai cara untuk meminimalisir risiko. Nilai mean sebesar 55,8 pada item 2 , artinya mahasiswa ratarata ingin berinvestasi karena mendapatkan pengetahuan tentang jenis-jenis investasi.

Hasil pengujian statistik deskriptif, minat mahasiswa Fakultas Ekonomi dan Bisnis Universitas Papua untuk berinvestasi dilihat dari aspek afektif dengan nilai maksimum yaitu sebesar 66 pada item 5 , artinya mahasiswa ingin berinvestasi karena kegiatan sosialisasi Pasar Modal diadakan secara gratis. Nilai minimum sebesar 27 pada item 4, artinya mahasiswa ingin berinvestasi karena mahasiswa senang bertanya ketika dibuka sesi tanya jawab. Nilai mean sebesar 51,2 pada item 1 , artinya mahasiswa rata-rata ingin berinvestasi karena materinya mudah dipahami.
Kedua hasil analisa berdasarkan regresi linear berganda dan statistic dekriptif dibahas sebagai berikut:

\section{Pengetahuan investasi (X1) berpengaruh} terhadap minat investasi (Y). Hal ini sesuai dengan penelitian terdahulu yang dilakukan oleh Pajar (Pajar R. C., 2017) dan Ukhriyawati, (2017) yang menyatakan bahwa variabel pengetahuan investasi juga memiliki pengaruh terhadap minat investasi.

Berdasarkan hasil uji t, variabel pengetahuan investasi (X1) mempunyai nilai beta sebesar 0,210 atau $21 \%$, artinya besarnya pengaruh pengetahuan investasi (X1) terhadap minat investasi (Y) sebesar $21 \%$.

Pengetahuan jenis-jenis investasi yang paling diketahui mahasiswa adalah tentang investasi saham. Pengetahuan jenisjenis investasi yang kurang diketahui mahasiswa adalah tentang investasi emas dan cara transaksi saham melalui aplikasi. Pengetahuan investasi tentang jenis-jenis investasi yang rata-rata diketahui oleh mahasiswa adalah tentang real investment atau investasi pada asset berwujud seperti tanah dan properti.

Pengetahuan mahasiswa Fakultas Ekonomi dan Bisnis Universitas Papua tentang return atau pengembalian investasi yang paling diketahui adalah tentang keuntungan dapat meningkatkan nilai uang 


\section{Nominal: Barometer Riset Akuntansi dan Manajemen \\ P-ISSN: 2303-2065 E-ISSN: 2502-5430 \\ Volume 9 No 2 (2020)}

di masa depan dan keuntungan investasi di Pasar Modal. Pengetahuan tentang return investasi yang kurang diketahui mahasiswa adalah tentang yield / imbal hasil seperti dividen yang merupakan laba perusahaan yang dibagikan kepada pemegang saham setiap tahunnya sesuai dengan kebijakan perusahaan. Pengetahuan investasi tentang return investasi yang rata-rata diketahui oleh mahasiswa adalah tentang pemahaman cara memperoleh keuntungan pada investasi saham.

Pengetahuan mahasiswa Fakultas Ekonomi dan Bisnis Universitas Papua tentang risiko investasi yang paling diketahui adalah tentang perubahan harga saham diakibatkan oleh permintaan dan penawaran saham. Pengetahuan tentang risiko investasi yang kurang diketahui mahasiswa adalah tentang capital loss, yaitu kerugian akibat harga jual lebih rendah dibandingkan dengan harga beli. Pengetahuan investasi tentang risiko investasi yang rata-rata diketahui oleh mahasiswa adalah tentang likuiditas asset, yaitu mudah tidaknya suatu asset diperjualbelikan.

\section{Pengaruh Motivasi Investasi (X2)} terhadap Minat Investasi (Y)

$$
\text { Motivasi investasi }
$$

berpengaruh terhadap minat investasi (Y). Hal ini sesuai dengan penelitian terdahulu yang dilakukan oleh (Pajar R. C., 2017),
(Situmorang, 2014), dan (Amhalmad \& Irianto, 2019) dinyatakan bahwa variabel motivasi investasi juga memiliki pengaruh terhadap minat investasi.

Berdasarkan hasil uji t, variabel motivasi investasi (X2) mempunyai nilai beta sebesar 0,583 atau 58,3\%, artinya besarnya pengaruh motivasi investasi (X2) terhadap minat investasi (Y) sebesar 58,3\%. Motivasi terbesar mahasiswa Fakultas Ekonomi dan Bisnis Universitas Papua secara intrinsik yang dimiliki mahasiswa adalah ingin mempersiapkan masa depan. Motivasi intrinsik terkecil yang dimiliki mahasiswa adalah ingin mendapatkan perasaan berharga dari teman-teman. Motivasi intrinsik yang rata-rata dimiliki mahasiswa adalah ingin mendapatkan penghasilan tambahan.

Motivasi mahasiswa Fakultas Ekonomi dan Bisnis Universitas Papua secara ekstrinsik terbesar yang dimiliki mahasiswa adalah telah mengikuti sosialisasi Pasar Modal. Motivasi ekstrinsik terkecil yang dimiliki mahasiswa adalah karena melihat iklan di TV. Motivasi ekstrinsik yang rata-rata dimiliki mahasiswa adalah karena investasi saham lagi nge-trend.

Data table 9 terlihat bahwa Nilai sig $F<0,05(0,000<0,05)$. Jadi, dapat disimpulkan bahwa $\mathrm{H}_{\mathrm{a} 1}$ diterima dan $\mathrm{H}_{\mathrm{o}}$ ditolak yang artinya bahwa pengetahuan 
investasi dan motivasi investasi berpengaruh signifikan terhadap minat investasi mahasiswa Fakultas Ekonomi dan Bisnis Universitas Papua.

Tabel 9: Hasil Uji Simultan

\begin{tabular}{|c|c|c|c|c|c|}
\hline Model & $\begin{array}{l}\text { Sum } \\
\text { of } \\
\text { Squar } \\
\text { es }\end{array}$ & df & $\begin{array}{l}\text { Mea } \\
\text { n } \\
\text { Squa } \\
\text { re }\end{array}$ & $\mathbf{F}$ & Sig. \\
\hline Regressi & 319.83 & 2 & 159.9 & 48.8 & .000 \\
\hline on & 0 & & & 34 & \\
\hline Residual & $\begin{array}{l}239.05 \\
2\end{array}$ & 73 & 3.275 & & \\
\hline Total & $\begin{array}{l}558.88 \\
2\end{array}$ & 75 & & & \\
\hline
\end{tabular}

a. Dependent Variable: Minat Investasi (Y)

b. Predictors: (Constant), Motivasi Investasi

(X2), Pengetahuan Investasi (X1)

Sumber : Data primer yang diolah 2019

Berdasarkan tabel 10 menunjukan nilai $R$ Square adalah sebesar 0,572 . Hal ini berarti $57,2 \%$ variabel minat investasi mahasiswa Fakultas Ekonomi dan Bisnis Universitas Papua dapat dijelaskan oleh variabel pengetahuan investasi dan motivasi investasi. Sedangkan sisanya $(100 \%-57,2 \%=42,8 \%)$ dijelaskan oleh variabel-variabel lain di luar penelitian ini. Tabel 10: Hasil Uji Koefisien Determinasi

\begin{tabular}{lllll}
\hline Model R & $\begin{array}{l}\text { R } \\
\text { Square }\end{array}$ & $\begin{array}{l}\text { Adjusted } \\
\text { R Square }\end{array}$ & $\begin{array}{l}\text { Std. } \\
\text { Error of } \\
\text { the } \\
\text { Estimate }\end{array}$ \\
\hline 1 & $.756^{\mathrm{a}}$ & .572 & .561 & 1.810 \\
\hline
\end{tabular}

a. Predictors: (Constant), Motivasi Investasi (X2), Pengetahuan Investasi (X1)

Sumber : Data primer yang diolah 2019

Pengetahuan investasi dan motivasi investasi berpengaruh secara bersama-sama terhadap minat investasi. Hal ini sesuai dengan penelitian terdahulu yang dilakukan oleh (Pajar R. C., 2017) yang menyatakan bahwa variabel pengetahuan investasi dan motivasi investasi memiliki pengaruh terhadap minat investasi.

Hal ini menunjukkan bahwa usaha yang telah dilakukan pihak Bursa Efek selama ini sudah benar, pada mahasiswa Fakultas Ekonomi, pengetahuan investasi dan motivasi berpengaruh terhadap minat investasi. Namun, berdasarkan data yang telah diolah yaitu tabel uji t, diperoleh hasil bahwa pengaruh motivasi investasi lebih besar dibandingkan pengetahuan investasi. Motivasi investasi memiliki pengaruh sebesar 58,3\% dan pengetahuan investasi sebesar $21 \%$.

Artinya sebanyak apapun pengetahuan yang diberikan oleh pihak Bursa Efek, akan kurang efektif apabila tidak memperhatikan motivasi yang dimiliki oleh mahasiswa Fakultas Ekonomi dan Bisnis Universitas Papua. Sehingga dalam setiap kegiatan yang diadakan oleh Bursa Efek Indonesia, selain memberikan pengetahuan investasi, perlu juga ditingkatkan motivasi mahasiswa untuk berinvestasi.

Sehingga dapat disimpulkan bahwa mahasiswa Fakultas Ekonomi dan Bisnis memiliki pengetahuan investasi yang baik serta motivasi untuk berinvestasi di Pasar Modal. Hanya saja untuk membuat mahasiswa benar-benar berinvestasi di 


\section{Nominal: Barometer Riset Akuntansi dan Manajemen \\ P-ISSN: 2303-2065 E-ISSN: 2502-5430 \\ Volume 9 No 2 (2020)}

Pasar Modal, adalah dengan lebih berfokus pada peningkatan motivasi mahasiswa Fakultas Ekonomi dan Bisnis Universitas Papua, bahwa dengan berinvestasi sama dengan mempersiapkan masa depan sejak dini.

\section{SIMPULAN DAN SARAN}

Variabel pengetahuan investasi

(X1) terhadap minat investasi (Y) mahasiswa Fakultas Ekonomi dan Bisnis Universitas Papua. Berdasarkan hasil yautu terdapat pengaruh sebesar $21 \%$ dan Variabel motivasi investasi (X2) terhadap minat investasi (Y) mahasiswa Fakultas Ekonomi dan Bisnis Universitas Papua. Terdapat berpengaruh sebesar 58,3\%.

Artinya dalam berinvestasi mahasiswa akan melakukan investasi ketika memiliki motivasi atau alasan dalam diri untuk mau melakukan. Meskipun mahasiswa mampu memahami atau memiliki pengetahuan terhadap untung ruginya dalam berinvestasi. Namun, hal itu tidak menjamin mahasiswa akan melakukan investasi. Mahasiswa memerlukan tambahan motivasi dalam melakukan investasi, motivasi bisa dari dalam atau diluar diri.

Secara simultas, Variabel pengetahuan investasi (X1) dan motivasi investasi (X2) terhadap minat investasi (Y) mahasiswa Fakultas Ekonomi dan Bisnis Universitas Papua terdapat pengaruh sebesar $48,83 \%$ dan $57,2 \%$ minat investasi dapat dijelaskan oleh variabel pengetahuan investasi dan motivasi investasi. Sedangkan sisanya $43,6 \%$ dipengaruhi oleh variabel lain di luar penelitan ini.

Artinya selain pengetahuan dan motivasi, masih terdapat variable lain yang akan mempengaruhi mahasiswa dalammenentukan apakah melakukan investasi atau tidak. Sehingga, bagi peneliti lain bisa melanjutkan dengan melakukan penleitian dengan menambah variable selain 2 variabel yang telah diteliti ini.

Bagi pihak Bursa Efek Indonesia, berdasarkan hasil penelitian, bahwa program memberikan sekolah pasar modal kepada mahasiswa fakultas ekonomi dan bisnis secara pengetahuan sudah baik. Namun, perlu ditambahkan materi terkait memotivasi mahasiswa dalam melakukan investasi. Agar setelah mengikuti sekolah pasar modal, mahasiswa akan bisa katif membuka akun investasi dan bisa bertransaksi secara aktif.

\section{DAFTAR PUSTAKA}

Amhalmad, I. \&. (2019). Pengaruh Pengetahuan Investasi dan Motivasi Investasi Terhadap Minat Berinvestasi Mahasiswa Pendidikan Ekonomi Fakultas Ekonomi Universitas Negeri Padang. Jurnal Ecogen, , 2(4), 734-746.

Apriyani. (2019). PELUANG MENABUNG SAHAM. Dipetik Juli 1, 2019, dari infobanknews.com: 
http://infobanknews.com/peluangm enabung-saham/

Bursa Efek Indonesia. (2019). Dipetik Juli 7, 2019, dari produk pasar modal: www.idx.co.id/produk/pasarmodal/,

FEB. (2019). Data Kemahasiswaan. Manokwari: FEB UNIPA.

Firyanti, I. \&. (2015). Analisis Faktor Faktor Yang Mempengaruhi Minat Mahasiswa Berbisnis Dengan Sistem Multi Level Marketing (Studi Kasus: Member PT . Melia Sehat Sejahtera). . E-Proceeding of Management, , (hal. 2(1), 716723.).

Ghozali, I. (2011). Aplikasi Analisis Multivariate Dengan Program SPSS. Semarang: BP Universitas Diponegoro.

Hadad, M. (2015.). Buku Saku Otoritas Jasa Keuangan Edisi Ke 2. Manokwari: Otoritas Jasa Keuangan.

Halim, A. (2005). ANALISIS INVESTASI. Jakarta: Salemba Empat.

Indonesia, P. S. (2019). Jumlah Investor di Galeri Investasi Universitas Papua. Papua Barat: BEI.

JKadir, A. M. dan Machasin (2014). Pengaruh Ability, Motivasi dan Pengembangan Karir terhadap Kinerja Karyawan Redaksi PT. Riau Pos Intermedia Pekanbaru. JURNAL EKONOMI Volume 22(2, 42-58.

Khotimah, H. W. (2011). Pengaruh Sosialisasi Dan Pengetahuan Terhadap Minat Investor Pada Efek Syariah Di Pasar Modal (Survei Pada Nasabah PT Danareksa Sekuritas Cabang FE-UI Depok). .Jurnal Account, 423-433.
Krisnangningsih, D. (2019). Pengaruh Gaya Kepemimpinan, Motivasi Kerja dan Iklim Organisasi Terhadap Kepuasan Kerja Karyawan (Studi kasus pada PT. PeiHai International Wiratama Indonesia) Undergraduate thesis, UNIVERSITAS MUHAMMADIYAH JEMBER

Pajar, R. C. (2017). Pengaruh Motivasi Investasi Dan Pengetahuan Investasi Terhadap Minat Investasi Di Pasar Modal Pada Mahasiswa FE Uny. Profita, 5(1), 1-16.

Situmorang, M., Andreas, A., \& Natariasari, R. (2014). Pengaruh Motivasi terhadap Minat Berinvestasi di Pasar Modal dengan Pemahaman Investasi dan Usia sebagai Variabel Moderate (Doctoral dissertation, Riau University).

Sugiyono. (2017.). Metode Penelitian Bisnis Pendekatan Kuantitatif, Kualitatif, Kombinasi, dan R\&D. . Bandung: Alfabeta, .

Ukhriyawati, C. F. (2017). Kinerja Reksadana Pendapatan Tetap Dengan Menggunakan Metode Sharpe, Treynor, Dan Jensen. Jurnal Mebis (Manajemen Dan Bisnis), 2(2), 1-11. 